\title{
SENTUHAN ARSITEKTUR NUSANTARA PADA ILMU KONSTRUKSI BANGUNAN, STRATEGI MENINGKATKAN KUALITAS PENGAJARAN SECARA DARING
}

\author{
Ch. Koesmartadi ${ }^{1}$, Gustav Anandhita ${ }^{2}$ \\ 1,2. Lingkungan Manusia dan Bangunan dan Program Studi Arsitektur, \\ Fakultas Arsitektur dan Desain, Universitas Katolik Soegijapranata, \\ Jl. Pawiyatan Luhur IV/No.1 Semarang \\ Email: ch.koesmartadi@unika.ac.id
}

\begin{abstract}
Abstrak
Wabah Covid-19 yang melanda dunia saat ini menyebabkan dunia pendidikan khususnya arsitektur dipaksa untuk melakukan perubahan metode pembelajaran. Perubahan ini bermakna positif, karena kesempatan memasukkan sentuhan lokalitas pada setiap materi lebih terbuka. Komunikasi visual dalam pembelajaran yang dilakukan secara daring justru memiliki keunggulan, yakni Dosen dapat membuatkan materi pembelajaran dalam bentuk tayangan sketsa maupun komputasi yang sangat beragam lebih mudah dipahami oleh para mahasiswa ketika ditayangkan dalam layar personal komputer/ laptop ataupun handphone. Kesempatan inilah Dosen dapat menambahkan pengetahuan konstruksi lokal secara lebih mendalam. Agar program pengajaran konstruksi saat pandemi dapat menjadi formula yang lebih baik, maka dibutuhkan inovasi dalam hal visualisasi bahan ajar supaya lebih mudah dipahami oleh mahasiswa, sekaligus menambahkan sentuhan konstruksi lokal sebagai potensi per-Arsitektur-an Indonesia di masa depan. Keunggulan penggunaan handphone dan personal komputer/ laptop adalah tersedianya kemampuan fitur-fitur dalam alat tersebut, sehingga mahasiswa lebih leluasa menentukan fokus gambar konstruksi yang dituju dengan melakukan penjelajahan ke semua rangkaian konstruksi yang memiliki bentuk struktur tiga dimensi, khususnya lebih fokus pada penyelesaian atap yang menjadi karakter konstruksi arsitektur Nusantara.
\end{abstract}

Kata kunci: pembelajaran, pandemik, konstruksi, arsitektur Nusantara.

\section{Abstract \\ Title: A Nusantara Architecture Touch on Building Construction Science: A Strategy to Improve Quality for Online Teaching}

Covid-19 pandemic hit the world hard, causing so many pedagogical reconfiguration and alteration that forces the world of education to change its approach, particularly in the applied science of architectural. This shift seems to be positive in terms of time available to rediscover and realign its relevance towards local wisdom. Visual communication during online class appears to be more interesting due to its capability to showcasing appealing sketch on PC/laptop or smartphone. This situation gives teacher and lecturer even greater chance to accommodate indepth local construction materials. In order to achieve better formula, innovation are needed to boost visual appeal. By using online devices, students are capable of capitalizing features which ensure their understanding and focus through 3-D structures and visualization, especially towards roof that has been an instrumental character of Nusantara Architecture.

Keywords: teaching, pandemic, construction, Nusantara architecture. 


\section{Pendahuluan}

Saat ini dunia sedang dikejutkan dengan wabah covid-19 yang memaksa semua negara merubah cara hidupnya, termasuk Indonesia. Di Indonesia seperti negara-negara lain nampak belum siap menghadapi pandemik tersebut karena wabah tersebut belum nampak kejelasannya kapan selesainya, sehingga proyeksi penyelesaiannya pun belum jelas. Akhirnya semua bidang, termasuk bidang pendidikan mengalami proses perpanjangan belajar di rumah hingga sekarang, karena belum jelas obat anti virusnya, maka selama tidak dapat di prediksi akhirnya dunia pendidikan dipaksa banyak yang merubah menjadi program tahunan. Demikian juga dalam pendidikan arsitektur, sifat pengajaran dan materi pendidikan yang lebih fokus ruang sebagai kajian mau tidak mau harus merumuskan cara pengajarannya. Konstruksi khususnya yang bermuatan lokal pada kondisi biasa pun sulit dimengerti, sehingga pengajaran konstruksi muatan lokal sebenarnya dapat diajarkan secara daring. Oleh karena itu perlu strategi pembelajaran yang lebih akurat, karena selama ini sudah lama menatap perkuliaahan dengan sistem langsung di kelas, ketika kuliah langsung di kelas kita terbiasa memberikan materi melalui tayangan LCD dan diterima di ruangan bersama oleh para peserta. Kondisi pandemik saat ini memaksa kita untuk membuat cara perkuliaahan yang tepat sasaran dan memberi materi yang lebih mendalam. Cara sketsa yang fokus pada konsep serta komputasi memiliki ragam sajian memberi peluang akan lebih mendalammya pengajaran sehingga mudah fokus pada aplikasi.

\section{Metode}

Materi konstruksi membutuhkan pendalaman yang lebih rinci, karena materi ini terdiri atas detail-detail yang memberi pengertian secara mendalam. Konstruksi Nusantara memberi pengalaman tektonika yang sulit disajikan jika peserta tidak langsung memandang dan mendalami lewat peralatan yang dihadapinya. Sehingga untuk menjawab tujuan pengajaran agar dapat mencapai sasaran maka dicari metode yang memungkinkan penyajian lebih fokus dan lebih mendalam. Konstruksi Nusantara memiliki karakter sambungan yang membutuhkan pencermatan meliputi karakter gerak bertiga dimensi, sistem koneksitas yang sangat beragam, muatan tektonika yang perlu dijelaskan dengan cara membedah dan mengurai bagian-bagian sambungan, bahan kayu memiliki karakteristik berdasarkan sifat-sifat kayu serta keunikan cara merangkai koneksi hubungan konstruksi. Konsekuensi metode ini adalah terletak pada bagaimana membuat bahan dasar baik sketsa atau komputer yang memungkinkan mahasiswa peserta dapat mengarahkan sendiri fokus yang dituju yang tersaji di dalam tayangan komputer. Sehingga dalam setiap proses pembelajaran para mahasiswa dapat memperdalam sendiri melalui tayangan dengan memilih obyek konstruksi. Metode sketsa memiliki karakter muatan yang dituju sesuai minat dan pemikiran pembuat sketsa, sedang metode penyajian komputer dapat dilakukan secara detail namun kurang dapat memenuhi keinginan dan karakter pembuat, karena sangat tergantung pada kapasitas layanan komputer. 


\section{Hasil dan Pembahasan}

Banyak publikasi mengenai arsitektur tradisional telah terbit namun belum terlihat adanya usaha menjanjikan untuk mendayagunakannya sebagai bahan kajian terhadap kelompok arsitektur progresif; termasuk pada ilmu kajian struktur-konstruksi. Sementara itu perhatian terhadap arsitektur tradisional kurang menggembirakan, mengingat arsitektur tradisional lebih menekankan pada aspek kebudayaan; bukan aspek keteknikan ataupun aspek rasionalitas rancangan yang lebih populer. Dengan mengacu pada arsitektur bahan kayu sebelum abad ke-18; atau yang disebut "Arsitektur Kayu Nusantara", penjelajahan terhadap struktur dan konstruksi dapat dimulai dengan memanfaatkan publikasi arsitektur tradisional. Kajian untuk mengindentifikasi ciri-ciri struktural-konstruksional arsitektur kayu Nusantara diupayakan sebagai sebuah kajian arsitektur, bukan kajian kebudayaan.

\section{Bahan Dasar Kayu}

Pada sekitar abad ke-7 dan ke-8 masyarakat Pulau Jawa mencapai kejayaan di bidang pertanian sehingga perdagangan semakin luas dan berkembang. Mulai saat itu industri perkapalan berbahan dasar kayu terimbas perkembangan tersebut. Pada masa itu pula konstruksi kayu mulai diperkenalkan kepada rakyat melalui Adipati Santang yang mengajukan konsep pembaharuan rumah. Adipati mempercayai bahwa rumah dari batu itu berbahaya, sebab sela-sela batu mudah terkikis oleh air hujan. Seain itu rumah akan mudah roboh dan sukar memperbaikinya. Ia mempercayai bahwa rumah dengan bahan dasar kayu akan lebih ringan, mudah dikerjakan kembali apabila rusak serta mudah dilakukan pennggantian (Heinz, 1997: 37-38). Beberapa yang diungkap Frick, Koesmartadi (1999: 17) lebih banyak pada sifat-sifat kayu sebagai material yang tidak aka nada habisnya jika dikelola secara baik, kayu merupakan bahan mentah yang bias diproses dijadikan barang lain. Yang tidak kalah pentingnya adalah kayu mempunyai sifat-sifat spesifik yang tidak dapat ditiru oleh bahan lain yang dibuat manusia, missal kayu memiliki sifat elastic, ulet, memiliki ketahanan terhadap pembebanan yang tegak lurus dengan seratnya atau sejajar dengan seratnya.

Atas dasar inilah opini bahwa arsitektur tradisional mengusung penggunaan bahan dasar kayu yang cukup dominan menjadi semakin kuat. Selain banyak dijumpai pada daerah beriklim Tropis Indonesia, bahan kayu bersifat ringan dan tidak menyimpan panas sehingga sesuai untuk wilayah berpotensi gempa (Idham, Cholis: 2014: 89). Dengan konstruksi berbahan kayu maka diperlukan hubungan antar batang dan ini membutuhkan pengetahuan tektonika yang memungkinkan bentuk struktur berbahan kayu dapat dimengerti sebagai keunikan konstruksi. Konstruksi hubungan kayu memiliki karakter yang mengikuti serat kayu untuk pengoptimalan fungsi konstruksi. Dalam penyajian detail sambungan konstruksi kayu untuk konstruksi Indonesia yang memiliki cara dimensi tiga dibutuhkan sajian detail dengan fokus pada inti sambungan. 


\section{Esensi Atap dalam Arsitektur Nusantara}

Atap adalah bagian atas dari suatu bangunan yang penting, karena menaungi penghuninya secara fisik maupun metafisik. Permasalahan atap tergantung pada luas ruang yang harus dinaungi, bentuk dan konstruksi dan lapisan penutup yang dipilih (Heinz, Moediartianto 2004: 79). Menilik keragaman bentuk naungan atap ini agaknya menjadikan konstruksi atap sebagai sebuah komponen yang penting dalam arsitektur Nusantara.

Menentukan konstruksi atap yang baik adalah tugas yang rumit karena mempertimbangkan banyak faktor, antara lain bentuk, struktur konstruksi maupun bahan bangunan. Pembentukan atap berarti ada konsekuensi di bentuk luar dan dalam atap yang diciptakannya. Struktur dan konstruksi dibangun dengan sistem rangka batang atau plat serta bahan bangunan yang dipilih sebagai konstruksi kuda-kuda atap beserta pengaruhnya terhadap kemiringan atap (Heinz, 2004: 84).

Fungsi atap sebagai penaung dan peneduh adalah agar manusia dapat dapat hidup nyaman dan melakukan kegiatan tanpa harus diterpa derasnya hujan dan teriknya panas matahari. Dengan bernaung dan berteduh, seorang tidaak terpisahkan atau terisolasi dari lingkungan sekitarnya, itu berarti bahwa perasaan bersatu dengan lingkungan sekitarnya masih dapat diperoleh (Prijotomo. 2006: 198), ruang yang ternaungi lalu menjadi volume ruang dimana bernaung dapat melakukan sebagai mana mestinya. Merujuk istilah ini maka desain arsitektur memiliki konsekuensi yakni besar di bagian atas, karena berfungsi menjaga kenyamaman membebaskan manusia dari sengat mata hari dan curah hujan.

Posisi ini menyebabkan rumah atap miring berfungsi sebagai penaung juga maka memiliki konsekuensi sebagai konstruksi yang berat. Dugaan sementara bangunan beratap rangka batang dengan kemiringan logis bersama kriteria pergempaan bisa menjadi salah satu kriteria bangunan arsitektur Nusantara. Dugaan ini menjadi mengerucut menjadi dua kriteria yang saling bertentangan, satu sisi bila desain bangunan yang memperhatikan masalah iklim maka bagian atasnya lebih besar karena menaungi bawahnya. Disisi lain bangunan gedung yang memperhatikan masalah gempa bumi maka guna tetap stabil saat terjadi goncangan maka struktur bangunannya besar dibawah sehingga stabil. Keunikan dari struktur bangunan di Indonesia inilah yang mengemuka, mengkombinasikan dua kriteria yang saling bertentangan iklim dan gempa bumi. Dengan mau mengerti bahwa apa yang terjadi di arsitektur atap memiliki aspek penting dan bertentangan maka dapat dimengerti konstruksi atap yang ada di kepulauan Nusantara memiliki bentuk yang unik dan mampu menanggulangi berbagai masalah gempa dan iklim. Memberi pengertian kepada mahasiswa tentang atap dalam kondisi kuliah daring tentang esensi atap. Jika biasanya mereka mengetahui gambaran atap melalui kuliah, namun setalah era pandemik maka cara ini tidak bias di ikuti untuk beberapa waktu kedepan. Melalui sajian daring para mahasiswa dapat mengetahui dan mendalami sendiri melalui tayangan laptop maupun handphone, tugas penyaji 
mengarahkan detail yang menjadi fokus.

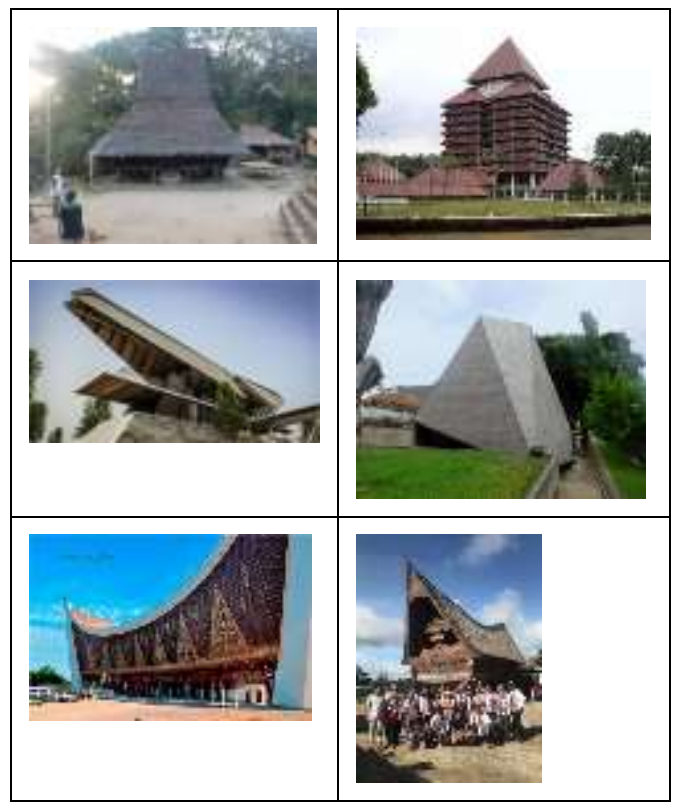

Gambar 1. Atap sebagai esensi Arsitektur Nusantara

Sumber: Dokumentasi pribadi

\section{Struktur Bangunan}

Struktur bangunan untuk bangunan di Indonesia merupakan elemen yang perlu dikaji bersamaan dengan aspek arsitektural karena masalah iklim dan pergempaan menuntut pembahasan yang menyeluruh utamanya dari kedua aspek.

Struktur dan konstruksi Nusantara merupakan istilah yang mengemuka di dalam kancah arsitektur Nusantara, karena dari bentuknya dan proses membangun struktur dan konstruksi Nusantara diduga memiliki pengertian yang beda dari rumusan yang umum mengemuka. Secara umum definisi struktur dan sistem konstruksi menurit Heinz Frick adalah sebagai berikut: struktur bangunan dan konsep arsitektur adalah dua sisi mata uang yang tidak dapat dipisahkan. Struktur bangunan tidak dapat ideal tanpa memperhatikan bentuk, funsi dan sistem bangunan, serta material. Sebaliknya konsep arsitektur tidak dapat dilakukan tanpa pemilihan struktur yang tepat. Kinerja banguan berkaitan dengan struktur karena sangat menentukan keselamatan penghuni (Idham, 2014: 61).

Struktur bangunan juga berkaitan dengan fungsi statis. Pernyataan fungsi statis dalam arsitektur tergantung pada bentuk struktur bangunan. Oleh karena itu dalam arsitektur sangat tergantung pada bentuk struktur bangunan, oleh karena itu studi sistem bentuk struktur bangunan mulai dari fungsi statis, hubungan bentuk dan gaya arsitektur dengan sistem konstruksi. Sistem struktur tidak selalu diwujudkan oleh bentuk bangunan karena fungsi statis adalah hanya satu faktor yang menentukan bentuk bangunan (Frick Henz \& Purwanto, 2007: 13). Sistem struktur untuk bangunan arsitektur Nusantara yang memang asli Indonesia agak sulit menggunakan difinisi struktur yang umum dipakai, karena memiliki pola kerja yang rigid diatas dan sedikit merusak tanah, sehingga pemikiran ini perlu dituangkan kedalam paparan yang lebih menjelaskan substansi.

\section{Struktur Rumit di Atas}

Arsitektur Nusantara memiliki konstruksi yang unik, dengan berbekal pengetahuan empiris dengan cara mencoba dan meralat yang dilakukan secara terus menerus. Faktor iklim dan gempa bumi yang merupakan faktor dominan menyebabkan bangunan rumah adat di Indonesia memiliki atap yang menjulang tinggi, besar diatas dengan bagian kaki yang sedikit merusak tanah. Dengan bentuk bentuk semacam ini memang dibangun berdasarkan pemikiran akan gempa dan iklim. Iklim mengharuskan 
bangunan berfunsi sebagai penaung dan peneduh maka memiliki ketiunggian, kemiringan dan besar di atas sebagai konsekuensi fungsi penaung. Bentuk yang beradaptasi dengan gempa bumi idealnya memiliki bentuk bangunan yang besar di bawah, secara logika benar adanya, Karena kurangnya ayunan saat gempa bumi.dan seimbang karena besar diatas. Permasalahannya faktor iklim kurang mendukung, sehingga ada konsep bentuk yang berlawanan satu sisi menghendaako besar diatas, sisi lain menghendaki besar dibawah. Entah itu kekuatan empiris karena kenyataannya memang begitu. Rumit di atas menginspirasikan kita bahwa konsttruksi sedang bekerja guna mengatisipassi kejadian alam seperti gempa bumi dan iklim. Kerumitan diatas mengandung arti struktur memberi kebabasan tiang yang menyentuh tanah dengan koordinasi konstruksi berada di bagian atas.

Salah satu karakter arsitektur di Indonesia yang dominan adalah atap miringnya yang berfungsi sebagai penaung sehingga punya konsekuensi berupa berat dan kerumitan di bagian atas yang berakibat pada berat dan besar atap. Kerumitan bermakna penyelesaian terhadap kondisi alam terutama iklim dan gempa yang mengharuskan desain bangunan membuat pertahahan keamanan sendiri karena dengan sedikit melukai tanah maka konsekuensi structural muncul di atas. Kerumitan di atas dapat ditampilkan dengan gambar gambar yang memiliki fokus tekanan kerumitan di bagian atas sehingga dapat dimengerti melalui gambar personal.

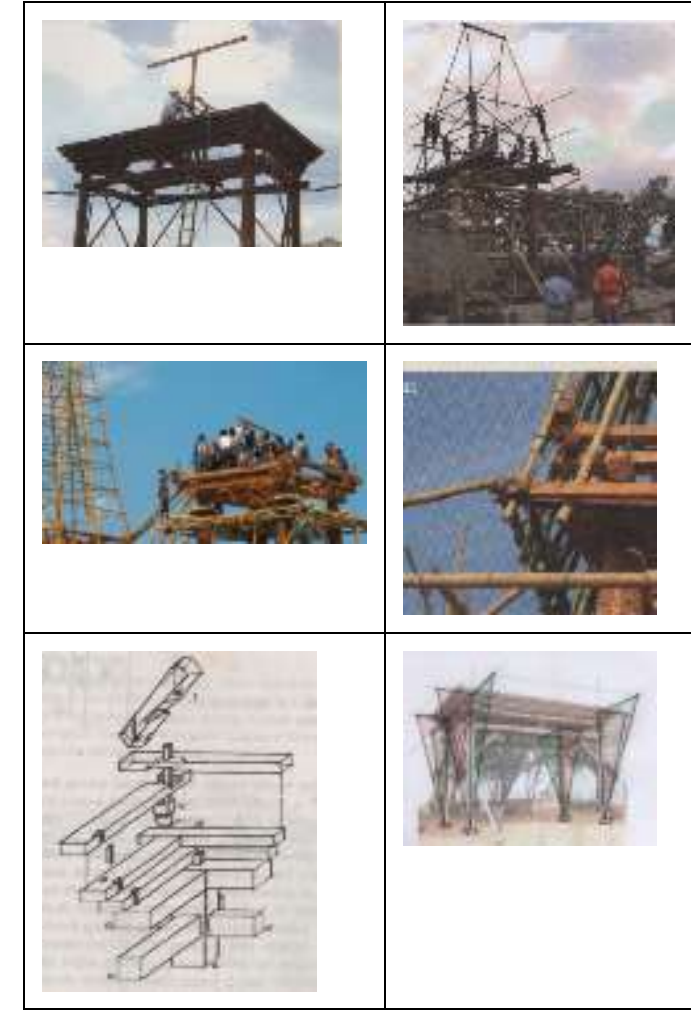

Gambar 2. Beberapa contoh bangunan yang menunjukan konstruksi yang rumit di bagian atas

Sumber: Dokumentasi pribadi

\section{Struktur Atap Lempengan}

Struktur bangunan yang ada di Indonesia pada umum nya memiliki bentuk struktur atap lempengan berupa susunan rangkaian konstruksi batang yang berjajar saling diragum menjadi satu kekuatan. Struktur lempengan di Indonesia seperti rumah adat yang umum membentuk rangkaian konstruksi dengan prinsip yang sama. Di Jawa dikenal dengan atap empyak, yang terdiri atas rangkaian empyak yang di tumpu menjadi limasan. Bidang empyak tersebut terdiri atas gaplok, usuk, tali ikat. Prinsip atap empyak juga memiliki kemiripan dengan bentuk bentuk lempengan arsitektur lainnya di lain tempat. 


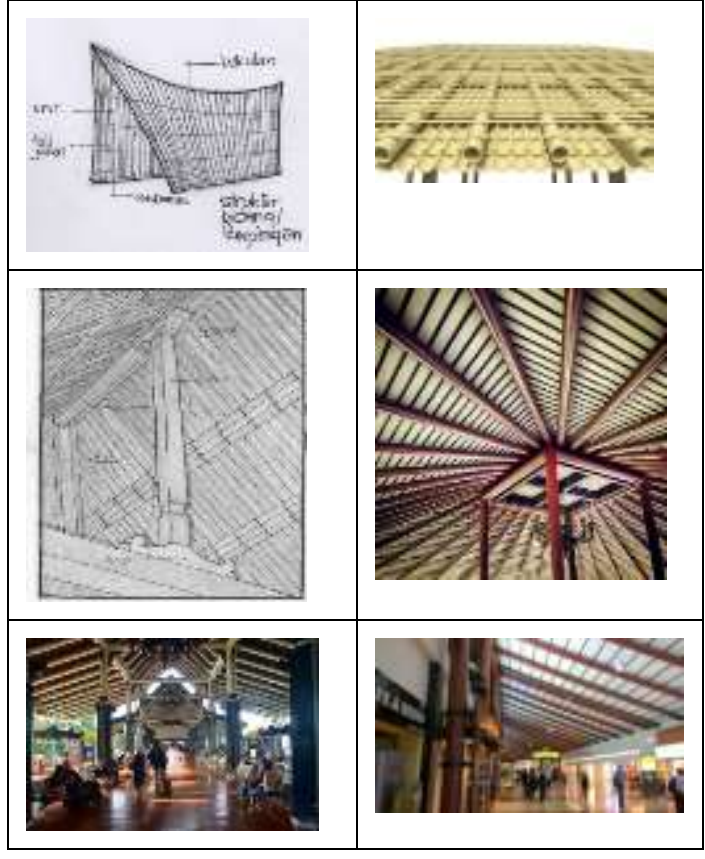

Gambar 3. Atap lempengan yang merupakan karya asli Indonesia yang sudah mengalami perkembangan Sumber: Dokumentasi pribadi

Pada struktur lempengan memiiki keunikan dan dalam tayangan kuliah daring mahasiswa dapat memilih fokus pada gambar lempengan tersebut. Struktur atap lempengan, meski sudah ada lama di Indonesia namun hingga hari ini tidak masuk kedalam khasanah keilmuan arsitektur. Maka untuk memberikan kuliah daring dibutuhkan pengetahuan dan kajian yang mendalam megapapa atap itu ada.

\section{Gempa Bumi}

Pada dasarnya hampir seluruh kepulauan di Indonesia dilalui cincin api berupa jalur gempa bumi dan peristiwa gempa bumi adalah kejadian wajar dan efeknya sangat merugikan manusia dan lingkungan sekitarnya.

Kerusakan besar akibat bencana gempa bumi seringkali disebabkan karena pengabaian bahaya dan kesombongan manusia. Sebenarnya beaya konstruksi yang digunakan untuk membangun sudah sangat berlebihan, namun penempatan dalam pemikiran aman gempa masih kurang. Prinsip bangunan aman gempa memperbolehkan bangunan mengalami kerusakan, bahkan runtuh ketika gempa terjadi, namun penghuni harus bisa diselamatkan (Idham, 2014: 29).

Yang menjadi fokus diskusi mengapa rangka atap cenderung bisa bertahan dan roboh secara utuh menimpa penghuni di bawahnya akibat tumpuan kurang bisa bertahan ikatannya? Ratarata atap yang roboh menggunakan prinsip rangka kuda-kuda kayu yang lazim digunakan di Belanda. Kuda kuda tradisional yang dipengaruhi oleh tukang-tukang dari Belanda masih banyak digunakan dan menjadi acuan dalam kurikulum konstruksi arsitektur di Indonesia (Frick, Heinz \& Setiawan, 2001: 204).

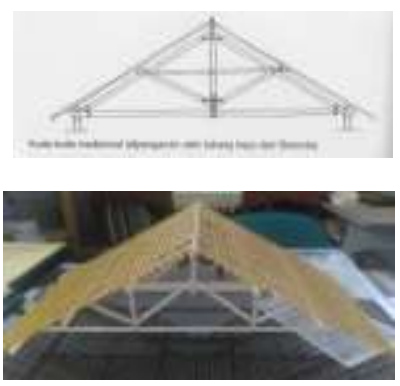

Gambar 4. Konstruksi kuda-kuda yang lazim dipakai dalam konstruksi di Indonesia.

Sumber: Dokumentasi pribadi

Sistem struktur kuda-kuda yang digunakan adalah sistem kuda-kuda rangka batang dengan dua tumpuan yang mengikuti kaidah roll dan sendi. Prinsip rol dan sendi sendiri menggunakan asas-asas mekanika teknik yang memungkinkan salah satu tumpuan mengalami pergeseran akibat muai susut ataupun beban. Meski demikian pada prakteknya hampir semua mengikuti kaidah jepit 
keduanya. Dari kedua rumusan tersebut diatas nampaknya apapun jenis tumpuannya tidak bisa mengantisipasi beban horizontal tegak lurus rangka kuda-kuda, karena kudakuda didesain untuk gaya-gaya sejajar dengan arah rangka kuda-kuda. Melihat bentuk rangka kuda-kuda maka dugaan beban maksimum ada di tengah konstruksi, sehingga saat terjadi gempa bumi maka ayunan kesamping sangat besar dan tidak dapat di pegang oleh kedua tumpuan.

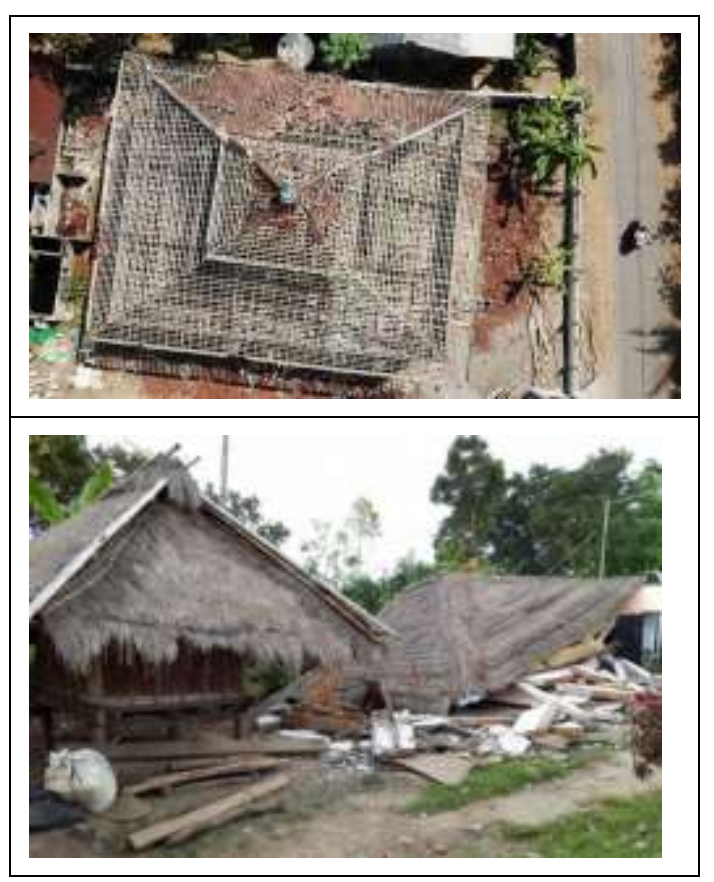

\section{Gambar 5. Gempa yang menunjukan kekuatan kuda-kuda yang dapat meruntuhkan bangunan Sumber: Dokumentasi pribadi}

Menurut Schodek (1999: 328) dalam mendesain sebuah struktur bangunan terutama di daerah gempa bumi struktur rangka tidak efisien apabila digunakan untuk beban lateral yang sangat besar, dianjurkan mengurangi lengan-lengan yang panjang karena sebuah konstruksi dengan momen yang besar cenderung membuat ayunan besar.
Secara grafitasi juga terlihat terjadinya momen yang besar ditengah rangka kuda-kuda maka kedua kolom tumpuanpun mengalami beban eksentris alias diluar kolom, akibatnya kolom-kolom bekerja kurang seimbang dan roboh. Kedua arah beban maksimum baik horizontal dan vertikal telah membuat bagian tengah rangka kuda-kuda mengayun secara vertikal dan horizontal dikendalikan secara bersamaan, akan tetapi badan rangka kuda-kuda pun cenderung utuh. Akhirnya tumpuanlah yang menjadi korban kerusakan konstruksi. Pada pemikiran ini dibutuhkan paparan yang membutuhkan pencerahan secara intensif yang dapat di lihat secara detail oleh peserta.

Mengapa gempa bumi menjadi hal uang belum diperhatikan didalam perencanaan bangunan gedung, melihat peristiwa gempa bumi di Indonesia sangat berdampak pada kerusakan dan nyawa manusia? Studi menyebutkan kebiasaan mendesain rumah dengan rangka atap kuda-kuda ketika terjadi gempa bumi maka struktur kuda-kuda tetap dalam rangkaian masih utuh, namun semua kaki kuda kuda rusak ataupun lepas dari tumpuannya, Penelitian sementara menyebutkan ketika terjadi gempa bumi rangkaian konstruksi kuda-kuda kaku bersama atap bergoyang secara massif hingga merusak kaki kuda kuda dalam setiap tumpuan. Seperti diketahui kebiasaan kita menggunakan sistem kuda-kuda hasil karya tukang-tukang Belanda yang mana ruang atap dipergunakan sebagai lantai loteng dan disanapun tidak ada gempa bumi sehingga cocok dan aman. Namun untuk dipergunakan di Indonesia memiliki dua masalah penting selain iklim yakni gempa bumi. Tidak heran 
konstruksi tersebut mudah roboh saat gempa bumi.

\section{Teknik Representasi Pembelajaran Daring}

Dalam konteks pembelajaran daring, hampir sebagian besar kegiatan mendesain dilakukan di depan komputer. Proses mendesain yang selama ini hybrid, yaitu menggunakan sketsa manual dan komputer, telah bergeser menjadi homogen hanya menggunakan komputer. Hal ini berdampak pada teknik representasi yang digunakan oleh mahasiswa. Padahal teknik representasi merupakan aspek terpenting dalam bidang desain yang berbasis visual seperti arsitektur.

Representasi menjadi jembatan antara ide yang bersifat abstrak dengan realita kita. Awal mula praktik arsitektur, ide yang berisi konsep, gagasan atau penjelasan direpresentasikan dalam bentuk sketsa. Lalu kemudian sketsa tersebut dikembangkan menjadi gambar terskala untuk mengeksplorasi dan menginvetigasi detail dalam desain tersebut . Dalam proses mendesain, sketsa ditempatkan di tahapan awal untuk mengkonstruksi ide dan gagasan secara cepat. Selain itu, sketsa dibuat untuk fokus pada informasi tertentu dan mengeliminasi informasi yang tidak relevan. Sehingga sketsa memiliki kelebihan dalam menangkap dan menyampaikan esensi ide gagasan tersebut.

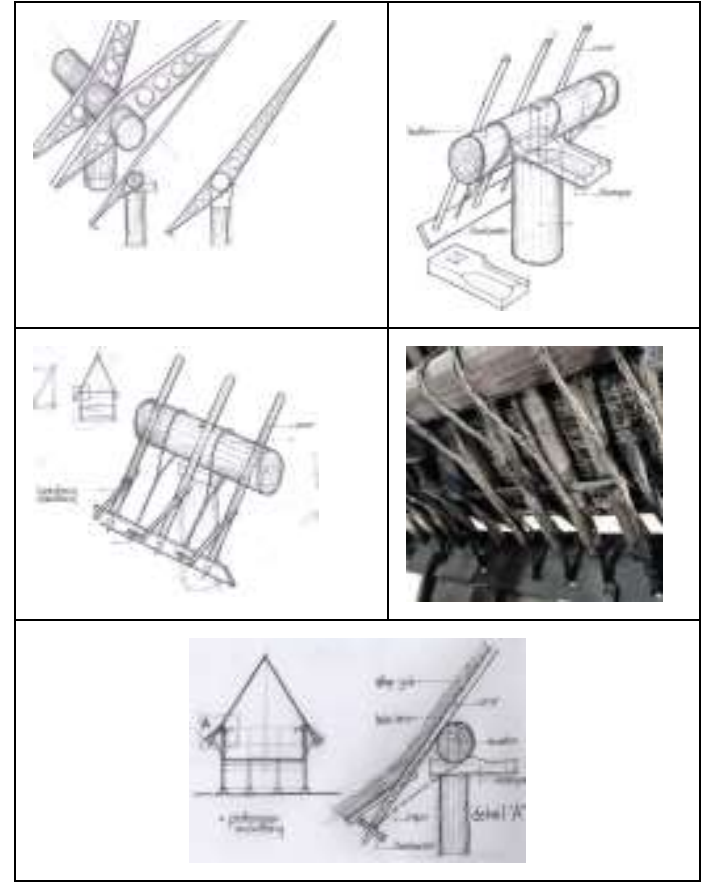

Gambar 6. Gagasan dalam perancangan yang umumnya dimulai dengan ide sketsa Sumber: Dokumentasi pribadi

Sketsa juga menjadi menjadi pijakan penting untuk menkonstruksi data awal sebuah informasi. Sebagai contoh proses pembuatan model digital arsitektur Jangga Dolok di bawah ini. Proses pengumpulan data, pencatatan detail dan pengukuran dilakukan dengan menggunakan sketsa. Kemudian sketsa yang sifatnya masih parsial tersebut akan direkonstruksi menjadi model digital yang lebih kompleks dan detail. Mahasiswa saat ini sudah begitu fasih menggunakan teknologi ini. 


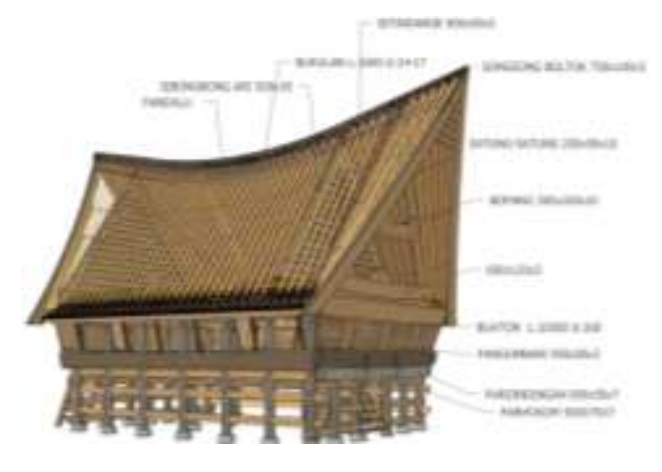

Gambar 7. Rumah Jangga Dolok Sumber: Dokumentasi pribadi

Sejak ditemukan tahun 80-an, teknologi CAD (Computer Aided Design) di komputer sudah mengambil porsi besar dalam proses mendesain. Bahkan, dalam konteks pandemi saat ini, mungkin komputer sudah mengambil semua porsi proses mendesain. Hal ini karena CAD menawarkan kemudahan dalam pembuatan detail konstruksi dan kemampuan pengolahan grafis yang menarik. Namun, perlu diketahui bahwa representasi model digital berbasis CAD sebenarnya tidak ada ubahnya dengan model fisik maket. Sekali sebuah model digital terbentuk, maka jika ingin melakukan perubahan terkadang harus memulai lagi dari awal, tergantung tingkat perubahan yang diinginkan. Tentu saja proses ini akan sangat memakan waktu mengingat teknologi ini juga dipengaruhi oleh kemampuan sumber daya manusianya dan spesifikasi komputer tersebut. Oleh sebab itu kemudian dikembangkanlah sebuah teknik baru yang dinamakan komputasi. Di tahap ini mungkin sebagian masih mencampur adukan istilah arsitektur digital, komputerisasi dan komputasi. Terdapat perbedaan siginifikan antara ketiga terminologi tersebut. Arsitektur digital adalah istilah yang digunakan untuk menjelaskan proses representasi arsitektur menggunakan gawai komputer. Kemudian penggunaan komputer tersebut dibedakan menjadi dua, yaitu komputerisasi dan komputasi. Perbedaannya, komputerisasi adalah proses menggambar menggambar representasi arsitektur menggunakan aplikasi grafis berbasis CAD (Computer Aided Design). Proses representasi pada komputerisasi tidak ada bedanya dengan menggambar di kertas, komputer hanya menggantikan peran meja gambar dan pensil. Sedangkan pada terminologi komputasi, teknik representasi diwujudkan dalam bahasa.

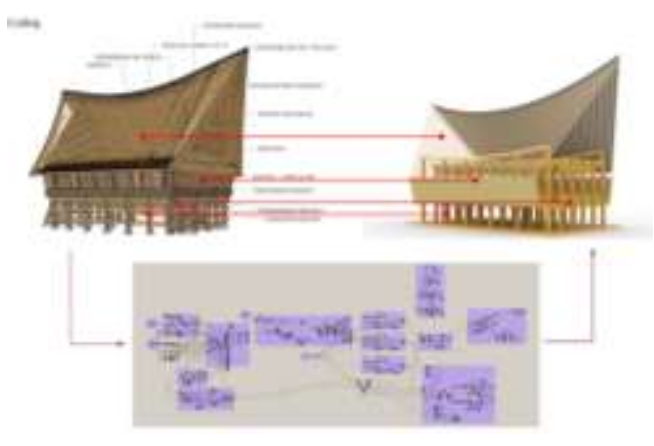

Gambar 8. Coding rumah Jangga Dolok Sumber: Dokumentasi pribadi

\section{Hasil dan Pembahasan}

Beberapa langkah telaah studi terhadap literatur maka dapat di jelaskan sebagai berikut: material kayu memiliki karakter berupa serat, lingkar tahun, lentur ringan sangat cocok untuk konstruksi di daerah tropis dan rawan gempa bumi, untuk itu karakter sambungan konstruksinya unik dan sangat tektonika. Model ini memiliki keunikan dalam hal teknik mengkonstruksinya maka diera pandemik ini teknik penyambungan dengan konfigurainya dapat lebih 
menarik disajikan melalui pembelajaran daring.

Esensi atap dalam arsitektur Nusantara memiliki arah pada sistem pernaungan yang mana bergabung dua masalah iklim yang menuntut bangunan dengan sudut tinggi dan lebar serta masalah gempa bumi yang bila tuntutan sedikit melukai tanah maka terjadi kerumitan dibagian atas sebagai langkah pengamanan terhadap kedua masalah tersebut, bentuk ini memberi peluang didalam sistem pengajaran daring karena rumit diatas dapat disajikan secara spesial sehingga dapat dilihat secara personal. Struktur bangunan di Indonesia memiliki keunikan yang tidak bias sekedar sistem penyaluran beban, katena didalam struktut tersebut terdapat konstruksi yang memiiki makna lebih mendalam dari sekedar sistem penyaluran beban.

Rumit di atas memiliki makna sebagai sistem perkuatan yang di geser keatas bagian atap sebagai perwujudan koordinasi perkuatan menghadapi gempa bumi dengan sistem bangunan yang besar di atas. Atap lempengan di Indonesia secara fisik sudah hadir jauh sebelum adanya teori-teori atap dalam arsitektur, namun secara teoritis belum masuk dalam tataran ilmu pengetahuan arsitektur karena memang teori-teori arsitektur tersebut belum dibukukan dan di pakai sebagai pembelajaran di kurikulum arsitektur. Di Indonesia menurut penelusuran semua peninggalan rumah adat diduga memiliki konstruksi atap berstruktur lempengan. Di Jawa konstruksi ini dikenal dengan konstruksi atap empyak dan sistem konstruksi jelas dan rinci mengikuti cara kerja konstruksi. Dalam kontruksi empyak ini masing masing bagian konstruksi bekerja sesuai dengan tugas dan fungsi masing masing bagian dengan sistem konstruksi ikat.

Gempa bumi merupakan peristiwa alam yang memang harus kita lalui sebagai penghuni kepulauan Indonesia, gempa bumi yang terjadi di pelosok Indonesia telah merusak bangunan dan nyawa penghuni. Banyak korban berupa kerusakan bangunan dapat dilihat secara nyata, sebuah pembelajaran yang luar biasa yang dapat dipergunakan sebagai sarana pembelajaran yang efektif terutama kerusakan-kerusakan yang terjadi di dalam konstruksi bangunan. Peristiwa ini sangat baik disajikan di dalam pembelajaran daring. Ketika mahasiswa belajar melalui layar personal maka fokus dan obyek kerusakan mudah dikenali.

Peningkatan kualitas pembelajaran metode daring yang dilakukan disaat pandemik ini merupakan langkah progresif ditengah masalah, dibalik peristiwa yang memakan banyak korban ternyata mampu menumbuhkan semangat baru berupa langkah progresif yang mampu memberi terobosan terhadap pengembangan ilmu pengetahuan dan teknologi arsitektur. Pengajaran melalui daring menumbuhkan keinginan untuk tampil secara lebih baik ditengah keterbatasan akibat tidak bertemunya fisik antar manusia. Program daring juga memiliki keunggulan yang tidak dapat ditemui di kondisi biasa ternyata dapat memberikan keunggulan dibidang teknologi suatu pertemuan yang biasa dilakukan dikelas terpaksa dirubah menjadi pertemuan secara daring. Pertemuan yang yang dilakukan secara daring memiliki juga keunggulan yakni dalam pertemuan semua mahasiswa duduk didepan layar karena memang sifat layar 
personal semua dapat mengoperasikan secara personal. Kemajuan teknologi peralatan ini bias menambah detail maksud pembelajaran ini karena peralatan ini dapat memperbesar detai gambar, bias untuk umpan balik karena ada alat responnya. Demikian juga ada cara presentasi secara dua arah. Kesempatan inilah yang dapat kita gunakan sebagai sistem pembelajara progresif yang tidak mungkin kita temui saat normal.

\section{Kesimpulan}

Setelah membahas peran daring dalam pengajaran dapat disimpulkan sebagai berikut: konstruksi Nusantara memiliki keunikan ragam dan sistem konstruksinya. Musim pandemik ini memaksa perguruan tinggi membuat trobosan dalam hal pengajaran. Metode pengajaran daring membuat keunikan konstruksi Nusantara dapat di tayangkan langsung ke mahasiswa karena dengan laptop, personal computer, dan HP kedua belah pihak baik dosen maupun mahasiswa dapat dapat memberi umpan balik melalui tayangan sketsa langsung. Kemajuan personal komputer, laptop, dan HP dapat mengatur fokus, membesarkan sehingga tayangan lebih mudah dimengerti.

\section{Daftar Pustaka}

Frick, H \& Koesmartadi, C. (1999). Ilmu bahan bangunan. Yogyakarta \& Semarang: Penerbit Kanisius \& Soegijapranata University Press.

Frick, H. (1997). Pola struktural dan teknik bangunan di indonesia. Yogyakarta: Penerbit Kanisius.

Frick, H. (2003). Ilmu konstruksi bangunan kayu. Yogyakarta \&
Semarang: Penerbit Kanisius \& Soegijapranata University Press.

Frick, H., Purwanto. (2007) Sistem Bentuk Struktur Bangunan. Yogyakarta \& Semarang: Penerbit Kanisius \& Soegijapranata University Press.

Frick, H., Setiawan. (2001). Ilmu konstruksi struktur bangunan. Yogyakarta \& Semarang: Penerbit Kanisius \& Soegijapranata University Press. Idham, N. C. (2014). Prinsip-prinsip bangunan arsitektur tahan gempa. Yogyakarta: Penerbit Andi.

Koesmartadi, C. (2019). Bernaung di bawah bayang-bayang atap. Semarang: Universitas Katolik Soegijapranata Press.

Prijotomo, J. (2004). Arsitektur Nusantara menuju keniscayaan. Surabaya: Wastu Lanas Grafika.

Prijotomo, J. (2006). (re)Konstruksi arsitektur jawa. Surabaya: Wastu Lanas Grafika.

Prijotomo, J. (2018). Prijotomo membenahi arsitektur nusantara. Surabaya: Wastu Lanas Grafika.

Schodek, L. D. (1999). Struktur (terjemahan). Jakarta: Erlangga. 